\title{
SYMPATHY, VOCATION, AND MORAL DELIBERATION IN GEORGE ELIOT
}

\author{
BY PATRICK FESSENBECKER
}

\section{SYMPATHY CHECKING DOCTRINES}

One of the most durable claims in the critical literature on George Eliot is that she rejects rule-based ethical theories. Jonathan Dancy calls Eliot the "Patron Saint of 'Particularism," a moral philosophy that insists on avoiding principles. ${ }^{1}$ Similarly, George Levine writes that Eliot argues for "the inadequacy of doctrine in relation to the particularities of human life and feeling," and "protests against the rigidity of systems."2 Suzy Anger agrees, writing that for Eliot, "[o]ne must figure things out case by case, feeling the rich particularity of each situation." ${ }^{3}$ This aligns, moreover, with a clear philosophical tradition that emphasizes the "uncodifiability" of ethics. ${ }^{4}$ As recent neo-Aristotelian thinkers have argued, it is a mistake to think that there could ever be moral algorithms. ${ }^{5}$ Learning how to apply ethical rules requires wisdom, and there is no deliberative procedure one can master that will yield the right answer in all cases. Instead, one must be sensitive to situational details.

Perhaps the primary textual basis for this claim is Eliot's notion that sympathy must "check" the application of moral doctrines. ${ }^{6}$ In Middlemarch, for instance, the narrator notes the self-deceiving reasoning of Nicholas Bulstrode, who has adapted his beliefs to satisfy selfish desire in believing that "money in the hands of God's servant" becomes "sanctified." But Bulstrode, the narrator explains, is not exceptional:

This implicit reasoning is essentially no more peculiar to evangelical belief than the use of wide phrases for narrow motives is peculiar to Englishmen. There is no general doctrine which is not capable of eating out our morality if unchecked by the deep-seated habit of direct fellow-feeling with individual fellow-men. ( $M, 668$, emphasis mine).

The Middlemarch narrator echoes a famous passage from The Mill on the Floss: 
$[M]$ oral judgments must remain false and hollow, unless they are checked and enlightened by a perpetual reference to the special circumstances that mark the individual lot. All people of broad, strong sense have an instinctive repugnance to the men of maxims; because such people early discern ... that to lace ourselves up in formulas of that sort is to repress all the divine promptings and inspirations that spring from growing insight and sympathy. . . And the man of maxims is the popular representative of the minds that are guided in their moral judgment solely by general rules, thinking that these will lead them to justice by a ready-made patent method. ${ }^{8}$

Both of these passages seem to suggest the importance of avoiding moral rules. Perhaps even more directly than the passage from Middlemarch, the passage from The Mill on the Floss indicates that there is no straightforward rule for making moral decisions. Such judgments will be "false and hollow"- the word "hollow" foreshadowing the "eating out" of moral doctrine in the Middlemarch passage-if they are not "checked" by sympathetic identification with other persons. Given the narrator's emphasis on the importance of "special circumstances" and the "individual lot," it is not hard to think that what "checked" really means here is overcome: in other words, the ideal moral agent largely abandons ethical principles in favor of a response to particular individuals and situations.

In keeping with this understanding of Eliot, critics have generally seen her place in intellectual history as fundamentally opposing the tradition of Kantian ethics, often held up as the example of principlebased ethics par excellence. As Annette Federico puts the point, "Eliot is not very interested in philosophical principles about how to act well," while Immanuel Kant "emphasized . . . applying universal law." Similarly, Anger claims that Eliot "rejects rationalist, rule-based moral systems such as Kantian or Utilitarian ethics, arguing that moral behavior should emerge not from the application of exceptionless moral principles but instead from attentive response to the complex particularities of a situation." 10 Such critics are not wrong. Kant does indeed offer an ethical decision procedure, and Eliot does indeed recoil from this way of thinking about moral deliberation. But this reading is importantly incomplete.

It is crucial that Eliot sees sympathy as "check[ing]" and "enlighten[ing]" doctrines and judgments rather than replacing them entirely. ${ }^{11}$ As Eliot puts it at one point, morality has two sides: a "theoretic and preceptive side" as well as an "emotional side." 12 The value of moral doctrines emerges particularly in Eliot's final rendering of this 
core component of her ethics, from The Impressions of Theophrastus Such, where the narrator refers to "the need of checks from a fellowfeeling with those whom our acts immediately (not distantly) concern."13 Here, the emphasis is on balancing principle-based moral actions with a consideration of their immediate impacts; as the narrator explains:

Wide-reaching motives, blessed and glorious as they are, and of the highest sacramental virtue, have their dangers. ... They are archangels with awful brow and flaming sword, summoning and encouraging us to do the right and the divinely heroic . . . but to learn what it is they thus summon us to do, we have to consider the mortals we are elbowing, who are of our own stature and our own appetites. ${ }^{14}$

Again, there is a need for sympathy to balance the application of moral judgments, but the narrator's description of such judgments is more charitable. Rather than using the somewhat pejorative term "men of maxims," Eliot here values the "wide-reaching motives" that principled beliefs about the good offer, suggesting that they can be morally beneficial. They are "glorious," leading agents to "do the right." This articulation makes clear what was implicit in the formulations from Middlemarch and The Mill on the Floss: sympathy cannot replace principled moral conceptions, which remain essential to agency, but must operate in concert with them. Eliot's ideal moral agent, then, is not an agent of pure sympathy, but instead one in whom sympathy and principle are constantly balancing each other. ${ }^{15}$

What is more, Kant's ethics of humanity, in which respect is constantly balancing our egoistic inclinations, offers an important philosophical analogue to Eliot's view. When one considers his claim that "respect is properly awareness of a value which checks my selflove," the existence of a close affinity between Kantian psychology and Eliot's theory of sympathy emerges ${ }^{16}$ Eliot's idea of checked doctrines, then, is in some important ways a version of Kant's categorical imperative, which requires the moral agent to test whether a personal maxim adequately accounts for the force of the reasons of others. Insofar as Eliot sees attention to others as necessary primarily because egoism can corrupt moral principles and thus covertly serve an agent's selflove, she echoes a Kantian theme. ${ }^{17}$

Let me be more precise. Kant's much-maligned universal law formulation of the categorical imperative- "act only in accordance with that maxim through which you can at the same time will that it become a universal law"-is really an attempt to articulate a formal principle for the stance of selflessness. ${ }^{18}$ Determining whether a possible principle 
of action (a maxim, in Kant's terminology) could be accepted from perspectives other than my own, which is what Kant thinks we do in considering whether a given maxim can be willed as a universal law, is the essential step in determining whether an action is both reasonable and moral. ${ }^{19}$ Indeed, it is the one precisely because it is the other. On Kant's picture of moral psychology, then, incentives generate possible actions and corresponding maxims, which are subsequently taken up and considered rationally-which, in a well-functioning moral agent, means they are submitted to the categorical imperative test. ${ }^{20} \mathrm{I}$ will argue here that Eliot's picture of moral deliberation is strikingly similar. Our principled conceptions of ourselves generate possible reasons for action, and in the process of acting those reasons are submitted to the testing or "check[ing]" process of sympathy, which insures they pass the test of selflessness.

My argument for this approach to Eliot proceeds in three steps. First, I show how Eliot's version of the gospel of work arises from her conviction that vocations supply agents with the possibility of principled reasons for action. After showing the importance of vocations for moral development, I argue that the difference between sympathy and respect, and correspondingly between Eliot and Kant, has been overstated. More than an impulsive feeling, sympathy emerges as a kind of deliberation aligned with generalizable principles and is thus a cousin to respect, involving a discriminating perception of the reasons of others. This is to say that principles matter in two senses: first, in the form of vocations, they are an essential part of autonomous self-constitution; second, sympathetic deliberation for Eliot is in fact closer to principled judgment than it at first appears. Finally, I turn to scenes from Adam Bede and Middlemarch as concrete depictions of sympathy in moral deliberation and action. Such scenes depend upon conflicts between an agent's principles and sympathetic perceptions, and correspondingly demonstrate the dual commitments in Eliot's moral thought.

\section{THE “GREAT CENTRAL GANGLION” OF MORAL LIFE: VOCATIONS AND SELF-CONSTITUTION}

Perhaps Eliot's clearest explanation of the importance of moral principles comes in her novella Janet's Repentance. After admitting that the Rev. Tryan's evangelicalism had drawn some hypocritical followers in the town of Milby, the narrator remarks: 


\begin{abstract}
Nevertheless, Evangelicalism had brought into palpable existence and operation in Milby society that idea of duty, that recognition of something to be lived for beyond the mere satisfaction of self, which is to the moral life what the addition of a great central ganglion is to animal life. No man can begin to mold himself on a faith or an idea without rising to a higher order of experience: a principle of subordination, of self-mastery, has been introduced into his nature; he is no longer a mere bundle of impressions, desires, and impulses. . . . The first condition of human goodness is something to love; the second, something to reverence. And this latter precious gift was brought to Milby by Mr Tryan and Evangelicalism. ${ }^{21}$
\end{abstract}

When we "reverence" something and hold its pursuit up above our desires, Eliot's narrator suggests that we undergo a moral awakening of sorts. To see something as worthy of devotion above and beyond whatever it offers moral agents in terms of desire-satisfaction raises such agents from a "bundle of impressions, desires, and impulses" to a "higher order of experience," which consists in "self-mastery." 22 The narrator here goes out of the way, moreover, to indicate that it is a benefit to all moral agents: "No man" can resist the higher order of experience achieved through the "subordination" of biological desire. Such experience is so much higher, in fact, that it is a condition of possibility for moral life: without the "great central ganglion" created by devotion to some "faith" or "idea," agents are essentially living an "animal life," driven only by the need to satisfy their impulses.

As Eliot's thought developed, she increasingly came to understand the achievement of self-mastery through reverence for an end as practically instantiated in a vocation. Tertius Lydgate's experience of a "moment of vocation" through which his "world was made new" becomes the regular form of moral transformation $(M, 152)$. As Alan Mintz has argued in a deservedly influential reading, "the experience of vocation" in Eliot involves the combination of two elements: "[T]he disciplined energy of the self and the commitment to end beyond the self. ${ }^{23}$ Of course, however, these elements are not independent, but mutually constitutive. As in Thomas Carlyle's famous account, work is morally beneficial precisely because it organizes wayward desires through the process of an agent's devotion to a goal. In Carlyle's distinctive metaphor, "a man perfects himself by working. Foul jungles are cleared away, fair seedfields rise instead . . . and withal the man himself first ceases to be a jungle and foul unwholesome desert thereby." ${ }^{.24}$ By forming a plan of life centered on an intrinsically worthwhile activity, one creates oneself as a person. And that's why the "Everlasting Yea" 
and the commandment to "work thou in welldoing" in Sartor Resartus comprise a "Gospel of Freedom." 25 Submission to a worthwhile task gives a new way of being free, because it offers the autonomy of selfmastery over the heteronomy of motivation by wayward desire.

That's to say that for Carlyle—and, I will suggest, for Eliot—work is more than work. The vocation is much more than the realization of an internal calling or the mere selection of a profession: it is instead the central element in what John Rawls would call a "conception of the good" and Christine Korsgaard would term a "practical identity." 6 As Rawls explains it, such a conception "normally consists of a more or less determinate scheme of final ends, that is, ends we want to realize for their own sake"; in Korsgaard's brief comment, a practical identity is a "description under which you find your life to be worth living and your actions to be worth undertaking." ${ }^{27}$ For both philosophers, our capacity to form an awareness of intrinsically valuable ends and to have that awareness determine our subsequent actions is what distinguishes us as persons..$^{28} \mathrm{~A}$ very similar conception of the self underlies the thinking about work in Eliot and Carlyle-it's not an accident that all four writers read Kant thoroughly.

Yet one difference is worth dwelling on. For Korsgaard and Rawls, the ongoing act of self-conception that gives rise to the experience of intrinsic value in worldly activities is purely an expression of our rational and autonomous nature. That's to say it's not a discovery in any sense, about either ourselves or the world. But for Carlyle and Eliot, the picture is slightly more ambiguous. On Carlyle's view, at its beginning the vocational process is not self-discovery but self-creation, a fact that indicates his alignment with Korsgaard and Rawls; Carlyle stresses particularly that we should not waste time trying to know ourselves before setting to work: "Think it not thy business, this of knowing thyself." ${ }^{\prime 29}$ However, once we do find something we can work at, we will discover that it has been the natural vocation for us all along, as "from the inmost heart of the Worker rises his god-given Force." 30 There is a residue, then, of an older conception of vocation, the idea of the secular "calling" traced so famously by Max Weber, on which the acquisition of an intrinsically valuable project is not an expression of choice or rational nature at all, but instead the expression of divine inspiration. ${ }^{31}$ If I must experience my vocation as a choice at first, as a setting to work, subsequently I will find that there was one correct, "god-given" choice. In a helpful shorthand, Jennifer Ruth has characterized the tension between these two conceptions of work as the tension between "being and doing." ${ }^{32}$ On the one hand, work is a thing 
I must actively do, that I must choose and reflectively endorse; on the other hand, ideally my work is just the thing that I am, an expression of my pre-reflective nature.

Like Carlyle, Eliot sees work in a way that intermingles the neoKantian voluntarist approach with the older sense of a calling. In particular, she relies on what one might term a theory of capacities: it is important that we freely choose our work and view it as an expression of our autonomous self, but the set from which we choose possible vocations is constrained by our abilities. This tension is central to Fred Vincy's narrative. On the one hand, Caleb Garth's advice to Fred stresses the extent to which he must regard his work as intrinsically valuable:

You must be sure of two things: you must love your work, and not be always looking over the edge of it, wanting your play to begin. And the other is, you must not be ashamed of your work, and think it would be more honorable to you to be doing something else. You must have a pride in your own work and in learning to do it well. $(M, 606)$.

What Caleb is claiming here is that work must follow from a conception of the good. As his notion that one has to love one's work reveals, for Caleb one must find the object of one's labors valuable in itself, and not see it only as valuable as a means to some other end. Correspondingly, to be ashamed of one's labor is in part to devalue its object, and thus shame creates a disparity between an agent's labor and his sense of what is valuable.

Yet not every profession will fit Fred. Although he has been trained for the clergy, he does not feel himself suited for it, and-what's more-Mary Garth, the woman he loves, says that she could not love him as a clergyman, because she "can never imagine him preaching and exhorting and pronouncing blessings, and praying by the sick, without feeling as if [she] were looking at a caricature" $(M, 560)$. Thus Fred's identity is not entirely up to him: should he establish a stable self, it will not solely result from the process of self-constitution a vocation enables. Rather, it will be the product as well of a kind of self-exploration: we don't know in advance what we are going to be good at, and the only way to find out is to try a variety of projects.

A famous passage from Middlemarch captures the religious and moral force of work in Eliot's view of the fully-formed, ideal moral agent:

Caleb Garth often shook his head in meditation on the value, the indispensable might of that myriad-headed, myriad-handed labour by 
which the social body is fed, clothed, and housed. It had laid hold of his imagination in boyhood . . . had acted on him as poetry without the aid of poets, had made a philosophy for him without the aid of philosophers, a religion without the aid of theology. ( $M, 283)$.

We see in Caleb Eliot's ideal for the way a principled self-conception can give rise to what the narrator of Janet's Repentance called "something to live for beyond the mere satisfaction of self." 33 According to Mintz, this passage captures the way "work is pleasure" for Caleb. ${ }^{34}$ But to put it this way misses Eliot's emphasis on the distinction between acting to satisfy a desire and acting toward a goal one regards as intrinsically worthy. Far from thinking of it in terms of pleasure, Caleb has a frankly spiritual sense of business: it is a "religion [for him] without the aid of theology." This way of putting it is key, for it suggests a principled self-conception that has not hardened into a "doctrine" or been corrupted by egoism. As such, the vocation retains its ethical effectiveness: Caleb often "shook his head in meditation on the value" of useful labor, and Eliot's rhetoric - she refers to the "sublime music" of the hammer-functions to capture phenomenologically the world of labor in the value-laden way Caleb understands it $(M, 283)$.

And to go too long without establishing a vocation is to threaten the self with instability. Daniel Deronda reveals the importance of the principled life of vocation in recognizing that it is what he requires:

A too reflective and diffusive sympathy was in danger of paralyzing in him that indignation against wrong and that selectness of fellowship which are the conditions of moral force; . . . what he most longed for was either some external event, or some inward light, that would urge him into a definite line of action, and compress his wandering energy. ${ }^{35}$

What is crucial here is what Deronda is not looking for: namely, sympathy. This is a feature of his moral life that sympathy is in fact actively hurting; as we learn at one point, Deronda's sympathy "threatened to hinder any persistent course of action" $(D D, 364)$. And the idea of a vocation helps us to see why: Deronda has so much willingness to recognize the validity of diverse plans of life that he is in danger of not forming his own. Doing so would, after all, entail describing some goods and actions as more valuable than others and then working toward them, in what Deronda calls "a definite line of action" $(D D, 365)$. Despite the difficulty in achieving this state, Deronda believes it is necessary-that the "life of practically energetic sentiment" is "the best of all" possible lives and "for himself the only way 
worth living" ( $D D, 365)$. Though more sympathetic than Fred Vincy, Deronda ultimately suffers from the same problem-the lack of a vocation that would constitute a conception of the good and guide his future actions by positing a value in them.

Similarly, Daniel Deronda's Gwendolen Harleth lacks such a conception, a fact that Deronda recognizes and tries to point out to her. In one of their first substantive conversations, Gwendolen rather impatiently asks him what she should do with her life. Deronda responds not by recommending that she be more sympathetic, but that she become invested in something outside herself: "Try to care about something in this vast world besides the gratification of small selfish desires. Try to care for what is best in thought and action-something that is good apart from the accidents of your own lot" (DD, 446). Deronda thus recommends that Gwendolen look beyond the mere satisfaction of desires, "the accidents" of her situation, and find something worthy of being regarded as the "best." He is quite open on where this value could be found: when she asks what specifically she should do, he replies vaguely with, "many things" ( $D D, 446)$. We can see why Deronda responds in this way; the point is not to form some particular conception of the good instead of another, but simply to find one.

The psychology here is born out in an intriguing debate about how Gwendolyn should develop herself. In response to Deronda’s suggestion that she is ignorant, Gwendolen challenges the logic of his suggestion that she educate herself: "It is all like a dance set beforehand. I seem to see all that can be-and I am tired and sick of it . . . You say I am ignorant. But what is the good of trying to know more, unless life were worth more?" (DD, 451). In other words, Gwendolen is saying she finds life valueless, and since the claim that she ought to learn more presumably hinges on the previous claim that life is valuable and knowledge is useful for living, her feeling that life lacks value prevents the recommendation from having genuine force.

Deronda responds not by trying to prove that life is valuable in itself, but by asserting that knowledge would in fact create value-in his words: "[L]ife would be worth more to you: some real knowledge would give you an interest in the world beyond the small drama of personal desires . . . Is there any single occupation of mind that you care about with passionate delight or even independent interest?" (DD, 451, emphasis mine). The word "independent" is crucial: Deronda has in mind the notion of caring for something for its own sake, rather than as a means of satisfying a desire; this is to say that he is asking if she finds anything to be genuinely valuable. And we see 
his neo-Kantianism in his suggestion that value is not discovered but created. ${ }^{36}$ Gwendolen does not need to seek out some worldly activity that is obviously worthy; instead, she needs simply to move beyond the "small drama of personal desire" into the world itself, and trust that the pursuit of activities will create the value she seeks.

Yet if the principles of vocations are morally transformative, they are nevertheless inadequate by themselves, and require supplement and correction by the sympathetic awareness of others. It is telling that the narrator of Scenes of Clerical Life identified love and reverence as the two conditions for goodness. Properly understood, they are necessary conditions because they compensate for each other's failures. If vocations can direct the wayward psychic energies sympathy threatens to disperse, they are simultaneously vulnerable to the infection of egoism. As Mintz puts it, because vocation offers a "self-consuming ambition promising redemption," it can also be "a dangerously modern legitimation of egotism and self-aggrandizement." ${ }^{37}$ Eliot's principled moral agents are always in danger of losing hold of their originally selfless reasons for caring about their vocational projects, instead caring about the projects as satisfactions of selfish desire.

Perhaps Eliot's most sustained examination of the way egoism can corrupt an originally principled vocation is her portrayal in Romola of the monk Savonarola. In his claim that the "cause of his party was the cause of God's kingdom," Romola hears only "the ring of egoism":

Perhaps such words have rarely been uttered without that meaner ring in them; yet they are the implicit formula of all energetic belief. And if such energetic belief, pursuing a grand and remote end, is often in danger of becoming a demon-worship, in which the votary lets his son and daughter pass through the fire with a readiness that hardly looks like sacrifice; tender fellow-feeling for the nearest has its danger too, and is apt to be timid and skeptical towards the larger aims without which life cannot rise into religion. ${ }^{38}$

We see here an explanation of the tension between conceptions of the good and sympathetic fellow-feeling. On the one hand, agents cannot live merely on sympathy. As Daniel Deronda's experience shows (and as this passage explains), such lives can never "rise into religion," since no action will ever be charged with genuine value. ${ }^{39}$ On the other hand, a conception of the good, when lived without sympathy, can become a "demon-worship" that leads to the dismissal of the claims of specific individuals. With this understanding of the primary deliberative function of sympathy-its ability to constrain the expression of a vocation - it is now time to consider just what sympathy is. 
One of the striking features of the body of literature on Eliot and sympathy is how differently critics represent the fundamental act of sympathizing. On even basic topics like the content of an act of sympathy, what exactly it is one sympathizes with, or how sympathy affects an agent's subsequent actions, there is significant critical divergence and disagreement. One distinguished line of criticism, for instance, insists that sympathetic recognition involves fixing other individuals into categories on the basis of the conceptual terms of the sympathizer; an equally distinguished line suggests that sympathy involves questioning and rejecting one's use of general categories in order to grasp individual particularity. ${ }^{40}$ And within this second line of criticism, there are significant divergences in the various accounts of the kind of self-doubt sympathy induces. ${ }^{41}$ Yet another debate hinges on what it is exactly that elicits sympathy: in particular, an influential line of criticism has emphasized the extent to which sympathy is a visual reaction, a response elicited by a scene, while dissidents from this approach have seen sympathy as a cognitive act, a perception of other minds. ${ }^{42}$

This divergence is not surprising. Eliot's oeuvre describes and represents sympathy in a number of different and not immediately consistent ways. But recalling the role of vocations can clarify how these different representations and descriptions fit together. In particular, situating sympathy alongside vocation allows the importance of reasons to emerge: sympathy is fundamentally the act of grasping what reasons a person is acting on, and affectively identifying with them when they are genuinely selfless. It's worth recalling what Maggie Tulliver wants from her brother Tom: she wants him to see those facts about her actions that make her life something other than a "planless riddle" or more simply the reasons that make her actions purposeful and not random. ${ }^{43}$ The need for this parsing of reasons links sympathy inextricably to the concept of vocation, for sympathy thus involves inhabiting the identities of others in such a way that their ends - those projects they deem intrinsically valuable, and which provide them reasons for action-become clear.

Reading Eliot's account of sympathy this way builds off the work of two recent critics. First, Anger has emphasized the banal quality of most acts of sympathy; in her view of Eliot, ordinary interpretation of the world requires sympathetic hermeneutics to grasp the purposes of the people we talk to. As she puts it, the "correct interpretation of any utterance is grounded in the intentions of the speaker," and thus 
everyday, ordinary comprehension requires that one "enter imaginatively into the perspectives of others." 44 Second, Rae Greiner has suggested that sympathy involves the positing of another person within a narrative: as she puts it, "sympathizing with the other isn't a matter of seeing and knowing, much less being in contact with other bodies, but 'situating' the other in an imaginative narrative temporality." ${ }^{45}$ Rather than a "spontaneous eruption of emotion," then, successfully sympathizing requires seeing behavior "in the light in which the impartial spectator would view it." 46

These two accounts align with each other in an important way: to grasp someone's intentions is to situate them within a narrative. That act of situating requires grasping how their intention is a reason: in other words, to fit an intention within a story is to see how that intention makes an action comprehensible as a rational thing to do. Thinking about Eliot this way suggests why there would be such a tension about the use of general categories: understanding how someone is acting rationally is often limited by one's own perspective about what's reasonable, but it can also challenge that very perspective.

Seeing the role of reasons in the functioning of sympathy involves first noticing a dyad in Eliot's representations of intersubjectivity. Suggestively, a passage from Adam Bede calls sympathy "the one poor word which includes all our best insight and our best love." ${ }^{.47}$ Both are equally important: the awareness of the mental states of others is a necessary but not sufficient component, requiring the identification with another that comes with a loving relationship. It is possible in Eliot to have compassion without understanding, and it is possible to understand someone without having compassion. Tellingly, Eliot often represents "love" and "insight" as inadequate ethical responses on their own, implying that a combination of the two is necessary.

For instance, early in Adam Bede, Dinah Morris goes to visit Hetty Sorrel alone, in hopes of helping her move past her "little foolish, selfish pleasures" $(A B, 156)$. In particular, she senses that Hetty does not love Adam "well enough to marry him"; this recognition of Hetty's heartlessness "touched" Dinah "with a deeper pity" $(A B, 156)$. In the visit, Dinah tries to warn Hetty about forthcoming trials, and Hetty begins to cry, but Dinah misunderstands Hetty's actions as reflecting a genuine moral shift. The narrator explains: "Dinah had never seen Hetty affected in this way before, and with her usual benignant hopefulness, she trusted it was the stirring of a divine impulse. . . . But Hetty was simply in that excitable state of mind in where there is no calculating what turn the feelings may take from one moment to 
another" $(A B, 159)$. There's no question that Dinah has compassion for Hetty; the narrator refers to "all the passionate pity that filled her heart" $(A B, 160)$. And certainly, Dinah identifies with Hetty, or at least tries to: her rhetorical efforts hinge on linking herself and Hetty under the umbrella of a "we" that is constantly erring. "We set our hearts on things which it isn't God's will for us to have," Dinah tells Hetty, and because "we" do this "we go astray and do wrong" $(A B, 159)$. But these efforts are crucially ineffectual, because Dinah does not understand what is going on in Hetty's mind, and Hetty simply becomes "irritated" $(A B, 159) .{ }^{48}$

At the other end of the spectrum, The Lifted Veil offers a thought experiment about the possibility of complete insight into the minds of others when the capacity is dissociated from any tendency towards pity or compassion. The narrator, Latimer, can hear without any impediment the "mental processes" of others, but far from identifying with them, he experiences them as an "obtrusion." 49 Latimer is distanced from other people, he explains, because when his telepathy opens other "souls" to him it shows them at their worst, showing "all the intermediate frivolities, all the suppressed egoism, all the struggling chaos of puerilities, meanness, vague capricious memories, and indolent make-shift thoughts, from which human words and deeds emerge like leaflets covering a fermenting heap. ${ }^{.50}$ What's striking here is that Latimer's experience of alienation comes in feeling the selfishness behind everyday actions. His sense of the "suppressed egoism" and "meanness" that really motivates the actions of other people explains why he finds them alienating: to see the "fermenting heap" of ego is to see actions as meaningless, driven only by selfish desires.

The contrast between Dinah and Latimer thus suggests that sympathy is not equivalent to the simple comprehension of others, or to compassion and pity for them, but instead involves a combination of the two-both "love" and "insight." The question, then, is how they work together. The implication of Latimer's story, it would seem, is that to see an action as selfless is to be able to identify with it. Accordingly, sympathy is both insight and love in the sense that it requires a cognitive recognition of the reasons of others and an affective identification with them. This is to reiterate the basic insight that sympathy involves inhabiting the perspectives of others and identifying with them, but it is to press the more specific point that such identifications involve recognizing the reasonableness of the reasons of other people.

Now, what's counterintuitive about this way of reading Eliot is that sympathy is often thought to be a reaction to the particularities of an 
individual's situation: a reaction not to her selflessness, in other words, but rather to all the rich specificity of that self. Understanding how Eliot negotiates this paradox - how an identification with other people's selfless actions is a way of identifying with that which is most deeply themselves - requires seeing the way Eliot reframes the Kantian tradition she inherits. As Andrew Lallier has noted, it is telling that Eliot thinks sympathetic moral feeling is a kind of "impartiality"; there's thus a peculiar sense in which sympathy can be an act of abstraction. ${ }^{51}$ In keeping with Eliot's suggestion that moral principles transform an agent from an animal life of mere self-satisfaction into a person with a "great central ganglion" capable of pursuing intrinsically valuable projects, to identify with someone's reasons is precisely to identify with the thing that makes her a person. ${ }^{52}$ The combination of instinctive compassion towards other persons with an awareness of them, where that awareness entails a grasp of their motivations for action and a discernment as to whether their actions are driven by reasons or selfish desires, suggests that in the final analysis Eliot's notion of sympathy is in fact a form of respect.

That combination isn't as bizarre as it seems: it's central to Ludwig Feuerbach's reformulation of the Kantian project. ${ }^{53}$ To briefly recall, the famous second formulation of the categorical imperative, the so-called formula of humanity, reads thus: "[S]o act that you use humanity, whether in your own person or in the person of any other, always at the same time as an end, never merely as a means"-or, as Kant says slightly earlier, "the human being and in general every rational being exists as an end in itself, not merely as a means to be used by this or that will at its discretion." ${ }^{54}$ Here, persons, since they are "end[s] in [them]sel[ves]," assume much greater prominence than they did in the universal law formulation. And central to the treatment of someone as an end in herself is the discernment of her reasons. Considering an example of the agent making a false promise in order to gain money, Kant explains deliberation under the formula of humanity thus:

$[\mathrm{H}] \mathrm{e}$ who has it in mind to make a false promise to others sees at once that he wants to make use of another human being merely as a means, without the other at the same time containing in himself the end. For, he whom I want to use for my purposes by such a promise cannot possibly agree to my way of behaving toward him, and so himself contain the end of this action. ${ }^{55}$

Under the formula of humanity, then, the morally relevant fact is whether I have sufficiently understood the person I am encountering, 
and in particular whether or not she would agree with what I am doing. ${ }^{56}$ To treat someone as an end in themselves, then, is to reflect on what their own ends - their own reasons - might be, and to consider whether my action is violating them.

Now, Kant tends to write as if respect is the only attitude capable of treating others as ends in themselves. However, David Velleman has recently offered a provocative interpretation of Kant's ethics on which love is also a reaction to someone's status as an intrinsically valuable end. As he puts it, love is like respect in being an "arresting awareness" of the "value inhering in its object." of our love is a person, and when we love him as a person-rather than as a work of nature, say, or an aesthetic object-then indeed, I want to say, we are responding to the value he possesses by virtue of being a person or, as Kant would say, an instance of rational nature" (LME, 365). To love a person is something different from loving an object, for it requires reacting to rational nature as such.

This view, Velleman contends, can make sense of some of our most powerful intuitions about love. When we say we want to be loved for ourselves-loved "warts and all" (LME, 370), loved "for myself alone" $(L M E, 363)$ and so forth-we do not really want to be loved for the particular, contingent characteristics of our identity. As Velleman points out, "someone who loved you for your quirks would have to be a quirk-lover, on the way to being a fetishist. . . . Who wants to be the object of someone's wart-love?" (LME, 370). Nor do we really want to be loved for our admirable characteristics, for this would imply a sort of comparison between possible beloved objects-for instance, being loved because one is more amusing than other possible beloved persons - that is incongruous with love. Rather, Velleman argues, "what we want is to be loved by someone who sees and isn't put off by our warts, but who appreciates our true value well enough to recognize that they don't contribute to it" (LME, 370). The mere fact that it is an emotion, in other words, does not require love to be a response to contingent identity: in fact, much of what makes love such a valued part of our lives is the way it responds to our rational nature as such, our selves through our warts.

Velleman's view has an antecedent in Feuerbach's reaction to Kant, and in Eliot's own development of Feuerbach's view. Feuerbach writes:

Man is an object of love because he is an end in himself, because he is a rational and loving being. This is the law of the species. . . Love, as has been said, is nothing else than the active proof, the realization 
of the unity of the race, through the medium of the moral disposition. ... Active love is and must of course always be particular and limited, i.e. directed to one's neighbor. But it is yet in its nature universal, since it loves man for man's sake. ${ }^{58}$

Feuerbach here emphasizes the impersonality of love, insofar as the end of the passage argues that love "is in its nature universal, since it loves man for man's sake." Notably, this is true despite the fact that it is limited to particular individuals. As such, Feuerbach claims that we love particular individuals in a universal way, which anticipates Velleman's argument that when we love a person, we are valuing their personhood.

Indeed, Feuerbach's conception of the "species" is a version of Kantian personhood. If in loving I realize "the unity of the race," then what I realize is essentially the way that I am like my beloved. But since I am essentially a rational and loving being, this is to say that to love is to realize the fact that the beloved person is also a rational and loving being. That's the thinking behind the circular-seeming idea that man is "an object of love" because he is a "loving being." To love a person is to realize their personhood, understood as their own capacity to love. Put this way, the boundary between reason and love begins to collapse, for both hinge upon a recognition of the universal aspects of personness through a particular instantiation. As Feuerbach puts it later, "Love is the subjective reality of the species, while reason is the objective reality." 59

On this view, it turns out, the primary difference between love and respect is the relation to other emotions; for Velleman, love "disarms our emotional defenses" and makes "us vulnerable to the other" in a way respect does not $(L M E, 361)$. To respect someone is to maintain a distance between oneself and them, but to love is to make oneself vulnerable. Eliot's account of sympathy makes it easy to see why and how this vulnerability appears: because sympathizing with someone's ends requires identifying with them in a way mere respect might not, sympathy requires altering and perhaps destabilizing one's own conception of which ends are worthwhile-that is, one's vocation.

Eliot's fullest articulation of this aspect of sympathy occurs in the story of Daniel Deronda. The narrator notes that he often experiences "a quick change of mental light, shifting his point of view to that of the person whom he had been thinking of hitherto chiefly as serviceable to his own purposes" (DD, 490-91). This sort of shifting, other passages make clear, is at the core of what it is to be sympathetic: 
"His imagination had so wrought itself to the habit of seeing things as they probably appeared to others, that a strong partisanship, unless it were against an immediate oppression, had become an insincerity for him. His plenteous, flexible sympathy had ended by falling into one current with that reflective analysis which tends to neutralize sympathy" $(D D, 364)$. As Audrey Jaffe points out, this passage somewhat confusingly repeats the word sympathy: Deronda's sympathy with others apparently negates the very sympathy he is deploying. ${ }^{60}$ But recalling the role of vocation can clarify how this negation functions. Deronda is worried about taking other people as means to his ends, and what gives him such worries is his ability to shift his "point of view," which presumably makes him recognize other persons as ends in themselves and therefore not appropriate as a means to his own ends. As such, he is continually doubting himself, always ready to recognize the projects of others as more worthy of pursuit than his own. Since projects are precisely what stabilize identity, however, to sympathize too much is to lose ahold of who one is. Thus, the implicit ideal is a balancing one, constantly checking one's own vocational commitments with awareness of other people.

By drawing on Velleman and Feuerbach, I hope to have shown then that sympathy is not necessarily opposed to respect. As Feuerbach's conception of love as an affectively charged attitude toward the value of personhood demonstrates, there is no necessary link between emotions, on the one hand, and the particular and contingent features of identity, on the other. It is possible, as Velleman argued, to respond affectively to the abstract qualities of personhood. Thus, in parsing and identifying with the reasons another person is acting upon, the love and insight that comprise sympathy are a response to the distinctive features of personhood. Eliot's fiction demonstrates its philosophical complexity in dramatizing this process of sympathetic engagement.

\section{SYMPATHY IN ACTION}

Perhaps the most straightforward example of sympathetic awareness correcting the application of moral principle in Eliot's fiction occurs at the end of Adam Bede. To recall the plot, Arthur Donnithorne comes to see Adam after abandoning Hetty Sorrel. Arthur is deeply repentant, and seeks Adam's help in persuading Hetty's family, the Poysers, to stay on the Donnithorne estates rather than leaving in protest of Arthur's actions; Arthur himself is joining the army. As he puts it to Adam, " $[\mathrm{O}]$ ne of my reasons for going away is, that no one else may 
leave Hayslope-may leave their home on my account. I would do anything, there is no sacrifice I would not make, to prevent any further injury to others" ( $A B, 467)$.

Now, as it happens, this project runs afoul of a principle Adam holds deeply. As he puts it to Bartley Massey, "Good come out of it! . . I hate that talk of people, as if there was a way o' making amends for everything. They'd more need be brought to see as the wrong they do can never be altered" $(A B, 459)$. Adam holds that to think good can come out of evil is to selfishly excuse oneself for one's evil actions, and to refuse to confront their real wrongness. And when Arthur asks for Adam's help, this principle causes Adam to refuse: "Adam thought he perceived in [Arthur's words] that notion of compensation for irretrievable wrong, that self-soothing attempt to make evil bear the same fruits as good, which most of all roused his indignation. . . . He felt his old severity returning as he said, 'The time's past for that, sir" $(A B, 467)$. What's crucial here is the emphasis on reasons for action. Adam criticizes the principle of evil coming from good because he thinks of it as stemming essentially from egoism-Arthur's idea is "self-soothing." An implicit distinction here emerges, following the distinction between acting on egoistic desire and acting on the basis of a genuine conception of the good. And as the novel shows, Adam's eventual decision to help Arthur rests on Arthur's demonstration that he is not merely acting selfishly.

Arthur demonstrates this first through an argument that he is giving up a great deal of happiness-in his words, the action "cuts off every piece of happiness I've ever formed" $(A B, 468)$. He then defends the notion of the Poysers staying, remarking, "[I]t is impossible for a sensible man like you to believe there is any real ground for the Poysers refusing to remain," and claims that Adam will be serving their good, not Arthur's own: "You know that's a good work to do for the sake of other people, besides the owner" $(A B, 469)$. This combination of repudiated egoism and endorsed value - the action is not for Arthur's own happiness, but it will be good for other people-begins to tell on Adam, who cannot "help being moved" $(A B, 469)$.

But this is not quite sufficient to persuade him to help. What finally convinces him is Arthur's appeal to Adam's ability to imaginatively identify with him. On the one hand, Arthur appeals to his own shame, unknowingly echoing Adam's regrets about his treatment of his father. "Perhaps you've never done anything you've had bitterly to repent of in your life," Arthur says; "[I]f you had, you would be more generous" $(A B, 469)$. On the other hand, Arthur appeals to their shared love of 
Hetty: "Haven't I loved her too?" ( $A B, 469)$. Taken together, these remarks force Adam into a new and deeper moral deliberation.

And what eventually leads him to alter his principles is his recognition of the commonalities between himself and Arthur. He explains his decision thus:

It's true what you say, sir: I'm hard-it's in my nature. I was too hard with my father for doing wrong. I've been a bit hard to everybody but her... . But feeling overmuch about her has perhaps made me unfair to you. I've known what it is in my life to repent and feel it's too late: I felt I'd been too harsh to my father when he was gone from me-I feel it now, when I think of him. I've no right to be hard towards them as have done wrong and repent. $(A B, 470)$.

We see here a clear instance of the phenomenology of sympathetic deliberation. In this case, Adam's recognition of Arthur's repentant perspective causes him to abandon his doctrine about evil coming from good, and instead claim "I've no right to be hard towards them as have done wrong and repent." Moreover, he calls his own treatment of Arthur unfair, and we can infer it is so precisely because Adam suspected egoistic impulse underlying Arthur's actions. Significantly, the shift toward seeing Arthur's true motives both causes and is caused by Adam's identification with Arthur: the stance of recognizing Arthur's selflessness and his commonality are one and the same.

Now, this scene shows a moral agent deciding to work towards someone else's ends upon recognizing the extent to which those ends are not merely the result of egoistic desire. There is an obvious corollary to this particular situation: namely, an agent who decides not to work toward someone else's ends upon recognizing the fact that they are the result of egoistic desire. This is the pattern followed by one of the most complex acts of moral deliberation in Eliot's novels: Dorothea Casaubon's decisions regarding her husband's requests about his opus, The Key to All Mythologies.

Famously, Dorothea Casaubon is in search of a vocation, but has no very clear idea about how to find one: "Her mind was theoretic, and yearned by its nature after some lofty conception of the world" ( $M$, 51). Indeed, she doesn't deny her uncertainty, describing her "belief" thus: "[T]hat by desiring what is perfectly good, even when we don't quite know what it is and cannot do what we would, we are part of the divine power against evil" $(M, 427)$. Now, this belief is clearly useless as a guide to action. As Dorothea admits, she doesn't know in any substantive way what actually is "perfectly good." It is instead 
the empty frame of a vocation: Dorothea recognizes precisely what a vocation should do, but her plan of life lacks any of the substantive content that would offer guidance toward specific actions. She hopes to fill in this content by marrying Edward Casaubon, finding meaning in service to him and his scholarly work. But tragically, Casaubon is not in fact selflessly devoted to that scholarly work; instead, it has become an expression of self-centered desire, with his conception of the good corrupted by egoism. Lacking "the ardor of a passion" that would "rapturously transform" his life, Casaubon is instead famously imprisoned by his "small hungry shivering self" $(M, 314)$.

Dorothea's inability to perceive this fact about her husband is made clear in a famous passage:

\begin{abstract}
We are all of us born in moral stupidity, taking the world as an udder to feed our supreme selves: Dorothea had early begun to emerge from that stupidity, but yet it had been easier to her to imagine how she would devote herself to Mr. Casaubon, and become wise and strong in his strength and wisdom, than to conceive with that distinctness which is no longer reflection but feeling-an idea wrought back to the directness of sense, like the solidity of objects - that he had an equivalent centre of self. $(M, 243)$.
\end{abstract}

Though she has started to emerge from it, Dorothea remains partially caught in a kind of egoism, seeing the world only insofar as it fulfills her needs. Accordingly, Casaubon is "wise and strong," which fulfills her need for an object worthy of devotion.

The second half of the passage, where the narrator explains what a sympathetic perception of Mr. Casaubon would entail, is more difficult to understand than has sometimes been acknowledged. Sympathy with Casaubon is apparently to "conceive with a distinctness which is no longer reflection but feeling," the fact that Casaubon has "an equivalent centre of self" $(M, 243)$. One might suggest that what Dorothea does not recognize is Casaubon's vocation, but this is not quite right: after all, that's what she_-albeit mistakenly_-married him for. Rather, what Dorothea does not recognize is the way his vocation is imbricated with his egoism, or the extent to which he really does not have a vocation at all. Correspondingly, Dorothea does not recognize the way in which Casaubon's reasons are generated: she takes him to be acting selflessly in service of an intellectual project, whereas he is actually acting selfishly in service of his own desires. But most precisely, Dorothea does not feel this: she lacks the sort of affectively-charged perception of Casaubon's personhood that Feuerbach and Velleman describe. 
Dorothea achieves a correct perception of Casaubon slowly, only achieving it fully after his death. Her perception of Casaubon's egoism begins first with her recognition of the futility of his scholarly project (see $M, 254$ ). This recognition forms a central background to his subsequent request that she follow his wishes in the event of his death, without knowing precisely what those wishes might be (see $M, 519$ ). On the one hand, Dorothea is inclined to refuse the request because of the fruitless nature of Casaubon's labors, which she expects she will be required to continue and in which she no longer believes (see $M, 520$ ). On the other hand, however, she deeply pities Casaubon, and recognizes that to refuse him would be to hurt him: "[I]f she were to say, 'No! If you die, I will put no finger to your work'-[it] seemed as if she would be crushing that bruised heart" $(M, 520)$. Ultimately, it is this pity that compels Dorothea to comply: "[S]he could not smite the stricken soul that entreated hers" $(M, 523)$.

Now, this would appear to be a stereotypical moment of sympathy, but it is crucial that this is not the word the narrator uses: instead, the passage speaks of Dorothea's compassion and pity. This is because Dorothea has not properly understood her husband, and thus does not genuinely sympathize with him or identify with his ends. To the extent that she feels sorry for him, she does not love him the way Feuerbach argues one ought: caring only about his "bruised heart" is not a perception of Casaubon's whole person ${ }^{61}$ Her opinion of herself to the contrary, she does not understand the situation clearly. Specifically, she does not understand her husband's jealousy about her relationship with Will Ladislaw, and the corresponding fact that Casaubon's request will be in part an attempt to restrain her from further companionship with Will. "Might [Casaubon] not mean to demand some thing more from her than she had been able to imagine," Dorothea asks herself, "since he wanted her pledge to carry out his wishes without telling her exactly what they were?" $(M, 521)$. "No," she answers: "[H]is heart was bound up in his work only: that was the end for which his failing life was to be eked out by hers" ( $M, 521)$. Her egoism ironically appears here in her conviction of the reality of Casaubon's vocation. If his work no longer matters to her, she is still sure it matters to him.

And this egoism is only overcome when, after hearing of the codicil in Casaubon's will disinheriting her if she marries Will Ladislaw, Dorothea perceives Casaubon in a way she never did while he was alive. Without her pity clouding her judgment, Dorothea can see Casaubon for who he is: an egoist seeking to keep "his cold grasp on [her] life," whose "exorbitant claims for himself" had corrupted his "care for his 
own character" $(M, 535)$. There is an implication here: if Dorothea had perceived Casaubon correctly before his death, she would not have been willing to comply with his request. Thus, the conclusion of her deliberation is not an identification with her husband but rather a rejection of him. Accordingly, there are two sides to sympathy: if Adam Bede ultimately acts on another's behalf when he perceives his motivation by a genuine conception of the good, Dorothea ultimately refuses to act when she discerns that the agent's motivations are in fact selfish.

\section{VARIETIES OF EGOISM}

Now, there is an obvious problem with this way of understanding Eliot's conception of sympathy, one captured by a tension within the very word reason itself. As Korsgaard has noted, we seem to use the word to mean three different things. Most basically, it is the basis or consideration for someone's actions or beliefs, as in a phrase like $O h$, that's the reason he went to the store. At one remove, it indicates that the specific considerations on which someone acts or believes conform to certain generally understood principles, as in well, that's a reasonable thing to think. And at a final or fundamental level—as capital- $\mathrm{R}$ Reason-it indicates our capacity to conform our beliefs and actions to such principles ${ }^{62}$ To put the claim of the three preceding sections in these terms, it is upon parsing whether an agent's reasons are in fact reasons - that is, whether the considerations on which someone acts pass the test of selflessness and therefore of rationality-that Eliot's sympathetic agents identify with the reasons, precisely because they are expressive of Reason, the person's rational nature. Yet this seems like an oddly limited view of sympathy as a moral reaction, insofar as it is impossible to ever sympathize with someone who isn't already acting selflessly. To return to Eliot's own terms, it seems impossible to sympathize with agents lacking vocations. One can certainly pity them-as Dinah pities Hetty-but it is not clear what sympathetic awareness of an agent who genuinely lacked a conception of the good would involve.

There is a minor cottage industry in categorizing the kinds of sympathy in Eliot's fiction, and one might deal with the interpretive problem this fact presents by simply saying that there are different kinds of sympathy, one for those with vocations and another for those without. ${ }^{63}$ But it seems to me more fruitful to think instead of different kinds of egoism. In particular, we might distinguish two types: the 
egoism of a corrupted vocation, in agents like Savonarola and Casaubon, and the egoism of developing individuals who have yet to achieve a vocation, like Fred Vincy and Gwendolen Harleth.

This issue lies at the center of what one might call scenes of sympathetic perception. Unlike scenes of sympathetic deliberation, which center on one agent sympathizing with another and subsequently deciding to act, scenes of sympathetic perception involve a sympathized-with agent recognizing the fact of sympathy. A sympathetic agent identifies not with another person's conception of the good-there is no such conception there, after all—but rather with her rational nature as such: her capacity to have such a conception, to be a better person than she is. Correspondingly, the identification lacks content, and so it takes less the form of a shared sense that something is valuable and shifts instead to a sort of trust.

In such instances, sympathy exerts normative pressure. The sympathizing agent manifests hope or faith, believing without or against evidence that the other person can be the kind of agent to whom something is valuable. There is a tension here between discernment and trust: ordinary deliberative sympathy seems to involve the recognition and rejection of egoism, but the attitude sympathizing agents extend to those who lack vocations seems to require the dismissal of such facts. Moreover, Eliot at some moments seems to prize the naiveté of sympathy: Dorothea's "simplicity," which holds "up an ideal for others in her believing conception of them," is "one of the great powers of her womanhood" (M, 829); similarly, Romola's simplicity gives her the aura of "noble womanhood." ${ }^{4}$ Upon closer look, however, it becomes clear that sympathizing perception achieves its power not by dismissing discernment but precisely by trusting despite the discernment of underlying egoism. Ideal sympathetic agents may trust some egoists and act on their behalf, when they discern that the egoism is not a permanent condition. In that sense, sympathy moves past respect in a crucial light, insofar as it is capable of discerning a split between egoistic agents' selfish reasons and their own better rational natures, and — upon discerning a lack of permanence—nevertheless dismissing the particular reason and identifying with the rational nature.

The famous scenes of sympathy at the end of Middlemarch enact this process. First, Dorothea Casaubon's affection exerts a considerable pressure on Will Ladislaw. The narrator explains:

There are natures in which, if they love us, we are conscious of having a sort of baptism and consecration: they bind us over to rectitude and 
purity by their pure belief about us; and our sins become that worst kind of sacrilege which tears down the invisible altar of trust. 'If you are not good, none is good' - those little words may give a terrific meaning to responsibility, may hold a vitriolic intensity for remorse. $(M, 829)$.

Because it makes us ashamed of our failures, it can be terrifying for someone who loves us to treat us as better people than we are. Here, the mere fact that Dorothea believes the best about Will-in other words, the evidence of her sympathetic perception of him-dramatically intensifies the force of the ethical injunctions that obtain on him. The power of this force testifies to the effects of being genuinely treated as an end in oneself. As Velleman suggested, love is a kind of perception-one that acknowledges but sees past one's warts to the person beyond them-and Eliot's terms "baptism" and "consecration" indicate that a person can be transformed simply by being perceived in a loving way. To agents who have not yet found a conception of the good, such affection creates a pressure to be more than a mere egoist, to act for something outside themselves. It is through such pressure that "pure belief about us" binds "us over to rectitude and purity": acting badly, out of egoistic desire, becomes a betrayal of the lover.

And subsequently, the most dramatic instance of this sort of sympathy occurs in Dorothea's encounter with Rosamond Vincy. Perhaps the oddest feature of this scene, as D.A. Miller notes, is the way Dorothea's sympathy compels Rosamond to act: Rosamond begins to explain that Will is not in love with her (and is really in love with Dorothea) "under the subduing influence of Dorothea's emotion" $(M, 857){ }^{65}$ But if Dorothea has subdued Rosamond, she has done so in an odd way. Rather than directly asking her to confess her sin, Dorothea has instead stunned Rosamond precisely by treating her as if she has acted rightly all along. Dorothea's "self-forgetful ardor," expressed in her refusal to be jealous of Will Ladislaw's affection for Rosamond, makes Rosamond feel a "bashful timidity" $(M, 853)$. More specifically, Dorothea identifies with Rosamond by drawing on her own failed marriage. She worries that she is "speaking as if she herself were perfection addressing error" and thus links herself with Rosamond in seeing both as suffering from the "awful" fact of the "nearness" of marriage $(M, 855)$. What makes this a kind of faith is precisely Dorothea's knowledge that Rosamond has been flirting with men outside her marriage; thus, in treating her as if she has been acting well, Dorothea manifests a belief in Rosamond that runs deliberately counter to the evidence. This faith is literally painful: it strikes 
Rosamond with "an overmastering pang" $(M, 853)$. In sum, Dorothea respects her capacity for rational action in regarding her as if she has not treated Lydgate badly, and such regard brings her egoism home all the more powerfully.

Yet the respect for rational agency inherent in Dorothea's sympathy can also be relaxing when that capacity has come under question. During the crisis at the end of Middlemarch, Lydgate stands under suspicion, for he is believed to have allowed a man to die at the behest of Bulstrode. However, Dorothea believes that he has not acted badly, and offers to listen to his explanation of his difficulties. This by itself is an immense relief:

Lydgate . . . saw Dorothea's looking up at him with a sweet trustful gravity. The presence of a noble nature, generous in its wishes, ardent in its charity, changes the lights for us: we begin to see things again in their larger, quieter masses, and to believe that we too can be seen and judged in the wholeness of our character. ... He sat down again, and felt that he was recovering his old self in the consciousness that he was with one who believed in it. $(M, 819)$.

The revealing notion here for our purposes is that of seeing and judging individuals on the basis of the "wholeness of [their] character," insofar as it links sympathy to the perception of someone's essential personhood. It is significant, further, what Dorothea is specifically assessing; she refuses to believe that Lydgate acted out of egoistic reasons. Her sympathetic perception sees clearly that, as the reader also knows, Lydgate has a clear vocation. But Lydgate's many frustrations have prevented him from acting in ways that serve his conception of the good, to the extent that he is beginning to lose sight of the way in which his actions are worthwhile and correspondingly experiencing dissolution of his identity. Dorothea's perception of him helps restore his sense of value: he can recover "his old self" because he is with one "who believed in it." ${ }^{6}$ Thus, if sympathetic perception exerts a pressure on those who lack a conception of the good, it can offer relief to those who do.

\section{SYMPATHY AND SELF-CONSTITUTION, PHILOSOPHY AND LITERATURE}

Let me end by pointing out a problem, one that perhaps indicates the future possibilities of this approach to Eliot. The account offered here has contended that moral deliberation, for Eliot, involves a constant 
balancing and correcting between two features of the self. While the principled self-conception of a vocation offers a concrete guide to activities in the world, correcting for the distractions of wayward desire and for the potentially diffusive effects of sympathy, the selflessness inherent in sympathetic reactions to others insures that one's vocationally guided actions do not fade into egoistic self-promotion. But one might observe that, even if sympathy and vocation are opposed in moral deliberation, they are not always so opposed in moral development. For Fred Vincy and Esther Lyon, for instance, the development of a practical identity is not something different from their development of the ability to sympathize: Fred's decision to learn how to manage property, for instance, is part of the same narrative that sees him learning to see his actions from the perspectives of other people. If that's true, then perhaps sympathy and vocation for Eliot are aligned at some level underneath their opposition in moral deliberation.

To come at the same point from a more overtly philosophical direction, in one sense there's an odd redundancy in Eliot's view. Sympathy and vocation both seem to solve the same problem: egoism. If sympathy imposes the test of selflessness on one's actions, it's worth remembering that the idea of intrinsically good ends-projects that could be willed for their own sake, not merely because they satisfied egoistic desire-was central to the definition of a vocation in the first place. So why, one might ask Eliot, does moral agency require both? Kant didn't think it did: respect for the moral law, properly understood, affords both the possibility of autonomy for the moral agent and a test for whether individual actions are morally permissible. The ability to act rationally in a way that overcomes the heteronomy of desire and the stance of ensuring one's actions take the interests of other people into account aren't, at the end of the day, fundamentally different capacities. Noting this difference suggests one of two interpretive options. Perhaps sympathy and vocation are aligned in some fashion, in the same way respect and autonomy are aligned in Kant. On the other hand, perhaps Eliot's division between sympathy and vocation reflects a deeper objection to Kantian moral psychology, one this essay has not captured.

Answering these questions and perhaps even asking them requires a different kind of approach to Eliot than literary critics have tended to pursue. ${ }^{67}$ It ignores, for instance, the differences between Eliot's various novels, instead bringing together points of comparison from across her oeuvre to present her as a systematic thinker. More obviously, some might say it ignores their status as works of art by treating 
them overtly and straightforwardly as expressions of a view in moral philosophy. Such interpretive problems are too complex to address even cursorily here, but I am on record as disputing the assumptions behind these views of literature and literary interpretation. ${ }^{68}$ And aside from the methodological debates, there's a more specific reason to take a straightforwardly philosophical approach to Eliot.

The standard history of nineteenth-century moral philosophy holds that the most important alternative to John Stuart Mill's utilitarianism was the view, held by William Whewell and others, commonly called intuitionism. And although intuitionism never disappeared, utilitarianism gradually won out. ${ }^{69}$ But this account is only persuasive so long as one insists on denying that Eliot was a moral philosopher. Restored to her place in mid-Victorian thought, it becomes clear that Mill's utilitarianism was never the dominant victor in British thought it sometimes appears to be. If we take a broader view of what moral philosophy can look like, then Eliot's creative interpretation of the Kantian view, which varied on his account of autonomous rational nature and the role of respect by introducing an emotional dimension to moral deliberation, reappears as a sophisticated and widely popular rival to Mill's utilitarianism. And to insist on the literary nature of her works as their most important feature risks dismissing that fact.

\section{Bilkent University}

\section{NOTES}

This essay has been a long time coming. I wrote the first version of it ten years ago in my first seminar in graduate school at Johns Hopkins, and I am grateful for the insightful commentary from the many people who argued with me about this reading of George Eliot, then and since. More concretely, the Danish National Research Foundation made completion of this essay financially possible (grant number DNRF127), and I am grateful for their investment in literary studies.

${ }^{1}$ Jonathan Dancy, Moral Reasons (Oxford: Blackwell, 1993), 70-71.

${ }^{2}$ George Levine, "Introduction," in The Cambridge Companion to George Eliot (New York: Cambridge Univ. Press, 2001), 6.

${ }^{3}$ Suzy Anger, "George Eliot and Philosophy," in The Cambridge Companion, 81.

${ }^{4}$ Rosalind Hursthouse, On Virtue Ethics (New York: Oxford Univ. Press, 2002), 39.

${ }^{5}$ Hursthouse, 61.

${ }^{6}$ George Eliot, The Mill on the Floss (New York: Penguin, 1978), 627.

${ }^{7}$ Eliot, Middlemarch, ed. W. J. Harvey (New York: Penguin, 1965), 667. Hereafter abbreviated $M$ and cited parenthetically by page number.

${ }^{8}$ Eliot, The Mill on the Floss, 627-28, emphasis mine.

${ }^{9}$ Annette Federico, "Being Torn: The Mill on the Floss," Literature, Interpretation, Theory 12.4 (2001): 364, 363. See too J. Hillis Miller, who contends that Eliot's aesthetic style rejects a simple belief in the clear expression of the logos on which Kant relies (The Ethics of Reading [New York: Columbia Univ. Press, 1989], 67). 
${ }^{10}$ Anger, Victorian Interpretation (Ithaca: Cornell Univ. Press, 2011), 112.

${ }^{11}$ As D. A. Miller puts it, "Sympathetic fellowship is offered as an all-but-natural touchstone by which ideologies are tested and —at least in part-found wanting" (Narrative and its Discontents: Problems of Closure in the Traditional Novel [Princeton: Princeton Univ. Press, 1981], 155).

12 "Worldliness and Other-Worldliness: The Poet Young," in Essays of George Eliot, ed. Thomas Pinney (London: Routledge, 1963), 379.

${ }^{13}$ Eliot, Impressions of Theophrastus Such (New York: Harpers, 2006), 99.

${ }^{14}$ Eliot, Impressions of Theophrastus Such, 98.

${ }^{15}$ Other critics have noted Eliot's representation of moral agency as a sort of balancing between oneself and others. In particular, for Sally Shuttleworth, "the central drama" of Eliot's novels "arises from a clash between the protagonist's desire for individual fulfillment, and the demands of social duty" (George Eliot and Nineteenth-Century Science: The Make-Believe of a Beginning [Cambridge: Cambridge Univ. Press, 1984], xi). For Rachel Ablow, there is a problem of "how to eradicate selfishness while maintaining the self-consciousness necessary for ethical relationships" (The Marriage of Minds: Reading Sympathy in the Victorian Marriage Plot [Stanford: Stanford Univ. Press, 2007], 71).

${ }^{16}$ Immanuel Kant, Practical Philosophy, 5 vol., ed. Allen Wood, trans. Mary Gregor (New York: Cambridge Univ. Press, 1999), 5:73.

${ }^{17}$ In connecting Eliot and Kant, this essay joins a nascent tradition. For some time, the only critic to have read Eliot's ethics alongside a Kantian framework in a more than momentary way was K. K. Collins, "G. H. Lewes Revisited: George Eliot and the Moral Sense," Victorian Studies 21.4 (1978): 463-92. But in recent years, Valerie Wainwright, K. M. Newton, and especially Andrew Lallier and Dermot Coleman have explored Eliot's work in the light of Kantian moral philosophy. See Wainwright, Ethics and the English Novel from Austen to Forster (Burlington: Ashgate, 2007); Newton, "George Eliot, Kant, and Free Will," Philosophy and Literature 36.2 (2012): 441-56; Newton, Modernizing George Eliot: The Writer as Artist, Intellectual, Proto-Modernist, Cultural Critic (New York: Bloomsbury, 2011); Lallier, “Where Can Duty Lie?': George Eliot, Kant, and Morality," George Eliot-George Henry Lewes Studies 62/63 (2012): 66-89; and Coleman, George Eliot and Money: Economics, Ethics, and Literature (Cambridge: Cambridge Univ. Press, 2014). I refer to more specific points of connection below.

${ }^{18}$ Kant, 4:421.

${ }^{19}$ See Christine Korsgaard, "Kant's Formula of Universal Law, in Creating The Kingdom of Ends (New York: Cambridge, 1996), 77-105, esp. 79. The essay offers in particular a clever reconstruction of the kind of contradiction Kant thinks immoral maxims will encounter when they are submitted to the test, and thus of the relationship between rationality and morality.

${ }^{20}$ This is Korsgaard's view of Kantian psychology; see The Constitution of Agency: Essays on Practical Reason and Moral Psychology (Oxford: Oxford Univ. Press, 2008), 179 .

${ }^{21}$ Eliot, Scenes of Clerical Life, ed. David Lodge (New York: Penguin, 1987), 320.

${ }^{22}$ Newton has explained this feature of Eliot's thought well. "Service to such a vision or ideal," he claims, can "direct" an agent"s life: "It can channel the energy generated by impulse and also control its instability" (George Eliot: Romantic Humanist [Totowa: Barnes and Noble, 1981], 74).

${ }^{23}$ Alan Mintz, George Eliot and The Novel of Vocation (Cambridge: Harvard Univ. Press, 1978), 66-67.

${ }^{24}$ Thomas Carlyle, Past and Present, ed. Chris R. Vanden Bossche, Joel Brattin, and D. J. Trela (Berkeley: Univ. of California Press, 2005), 195. 
${ }^{25}$ Carlyle, Sartor Resartus (New York: Oxford Univ. Press, 1987), 140.

${ }^{26}$ John Rawls, Political Liberalism (New York: Columbia Univ. Press, 1993), 19; Korsgaard, The Sources of Normativity (New York: Cambridge Univ. Press, 1996), 101.

${ }^{27}$ Rawls, 19; Korsgaard, Sources of Normativity, 101.

${ }^{28}$ The phrase "conception of the good" is an update from Rawls's formulation of the notion of a "plan of life," which perhaps resonates even more strongly with the account of personhood I'm explaining here (A Theory of Justice [Cambridge: Harvard Univ. Press, 1999], 358). Particularly suggestive is Rawls's use of the idea from Josiah Royce that "a person may be regarded as a human life lived according to a plan" ( $A$ Theory of Justice, 358).

${ }^{29}$ Carlyle, Past and Present, 195.

${ }^{30}$ Carlyle, Past and Present, 196.

${ }^{31}$ Max Weber, The Protestant Ethic and The Spirit of Capitalism, trans. Talcott Parsons (New York: Routledge, 2001), 39. In chapter 3, "Luther's Conception of the Calling," Weber defines the "concrete calling" as "a special command of God to fulfill these particular duties which the Divine Will had imposed" (Weber, 44). For an eloquent Victorian iteration of this view of work, see John Henry Newman, "God's Will The End of Life," in Discourses Addressed to Mixed Congregations (New York: Longmans, 1906). There Newman writes that God "has an end for each of us; we are all equal in His sight, and we are placed in our different ranks and stations, not to get what we can out of them for ourselves, but to labour in them for him" (112).

${ }^{32}$ Jennifer Ruth, Novel Professions: Interested Disinterest and the Making of the Professional in the Victorian Novel (Columbus: Ohio State Univ. Press, 2006), 3. More broadly, the competing theories of freedom as self-expression and autonomy as selfconstitution are what Charles Taylor sees as the two key sources of the modern self (see Taylor, Sources of the Self [Cambridge: Harvard Univ. Press, 1988]).

${ }^{33}$ Eliot, Scenes of Clerical Life, 320.

${ }^{34}$ Mintz, 138.

${ }^{35}$ Eliot, Daniel Deronda, ed. Terence Cave (New York: Penguin, 2003), 364-65. Hereafter abbreviated $D D$ and cited parenthetically by page number.

${ }^{36}$ For J. H. Miller, Eliot confronted the rise of secularism with a recognition that principles were not founded on objective facts about the world, but instead rose from within subjectivity: "Each man casts outward on the world patterns of value which have no existence except in his own mind" (The Form of Victorian Fiction: Thackeray, Dickens, Trollope, George Eliot, Meredith, and Hardy [South Bend: Univ. of Notre Dame Press, 1968], 118). This is true, but Miller misses Eliot's use of Kant's key insight: the fact that a pattern is a projection from one's own mind in no way undermines its reality. As Korsgaard puts it, "The objects of value are just the things that are important to us, the objects of natural human interests. But the result values are not 'subjective' or given directly by those interests. Value springs from the act of rational choice" (Creating the Kingdom of Ends [New York: Cambridge Univ. Press, 1996], x, emphasis original).

${ }^{37}$ Mintz, 150. Mary Poovey's famous account of Charles Dickens's David Copperfield (1850) traces a very similar problem—-for both David Copperfield and Dickens himself, the overt pursuit of the selfless vocation of an author masks the self-aggrandizement underneath. There is a major difference, however, in Eliot's self-awareness: the possibility of the rise of such self-aggrandizement is by no means hidden beneath the surface of the work, but a key thematic issue. See Poovey, Uneven Developments: The Ideological Work of Gender in Mid-Victorian England (Chicago: The Univ. of Chicago Press, 1988). 
${ }^{38}$ Eliot, Romola (New York: Penguin, 1996), 501.

${ }^{39}$ Amanda Anderson has traced Eliot's analysis of the difficulty of living according to a principled self-conception; see "Living Theory: Personality and Doctrine in Eliot," in A Companion to George Eliot, ed. Anderson and Harry Shaw (New York: Blackwell, 2013), 442-56.

${ }^{40}$ Shuttleworth contends that sympathy involves precisely the use of general categories, as the act of sympathizing involves placing an individual in a taxonomy: "Sympathy, like classification, fixes its object" (George Eliot and Nineteenth-Century Science, 29). Audrey Jaffe has developed this insight, emphasizing the fact that since sympathy involves the imaginative representation of others on the basis of the sympathizing agent's "social and cultural identity," what is thus sympathized with is less the other person than a projection of that person (Scenes of Sympathy: Identity and Representation in Victorian Fiction [Ithaca: Cornell Univ. Press, 2000], 4). Thomas Albrecht has added to this scholarship by tracing the figurative language in moments of sympathetic awareness, showing how its features reflect not an awareness of the other but the idiosyncrasies of the sympathizing agent ("Sympathy and Telepathy: The Problem of Ethics in George Eliot's The Lifted Veil," ELH 73.2 [2006]: 437-63). But Catherine Gallagher has suggested that the standard view of Eliot's account of the ethics of sympathy is the recognition of the inadequacy of general categories: Dorothea Casaubon develops the capacity for sympathy when she becomes capable of seeing "others by imagining their particularity instead of pressing them into categories" "“George Eliot, Immanent Victorian," Representations 90.1 [2005]: 70). Caroline Levine's recent argument that sympathy is the product of a certain kind of surprise, one that jars moral agents out of their complacent self-satisfaction, aligns with this view (see "Surprising Realism," in A Companion to George Eliot, 62-75).

${ }^{41}$ On Elizabeth Ermarth's view, self-doubt is healthy, since it consists in an "ability to acknowledge mistakes" "“George Eliot's Conception of Sympathy," Nineteenth-Century Fiction 40.1 [1985]: 28). But for Ablow the self-questioning inherent in sympathy is much more troubling since it involves the abdication of self-control more generally: Maggie Tulliver's sympathy “makes her utterly subject to her desire and to [Stephen's] will” (The Marriage of Minds, 76). And for Ann Cvetkovich, self-doubt appears in an inability to keep secrets, as Daniel Deronda's sympathy turns him into "an authority from whom [Gwendolen] is afraid to hide anything" (Mixed Feelings: Feminism, Mass Culture, and Victorian Sensationalism [New Brunswick: Rutgers Univ. Press, 1992], 145-46).

${ }^{42}$ The visuality of sympathy for Eliot is one of the key themes for David Marshall; as he puts it at one point, "Daniel Deronda is about the interplay of theater and sympathy" (The Figure of Theater: Shaftesbury, Defoe, Adam Smith, and George Eliot [New York: Columbia, 1986], 194). Jaffe's Scenes of Sympathy, as is perhaps obvious, extends this approach. It has been questioned recently by Anger and Rae Greiner, who both emphasize the cognitive dimensions of sympathy (see Anger, Victorian Interpretation; and Greiner, Sympathetic Realism in Nineteenth-Century British Fiction [Baltimore: Johns Hopkins Univ. Press, 2012]). As will emerge below, my interpretation here aligns with this second or cognitive approach.

${ }^{43}$ Eliot, The Mill on the Floss, 409. As Jonathan Loesberg has brought out, there is a sense in which sympathy grows from the experience of unreadability - the recognition that an action is not immediately comprehensible. Tom thinks he has comprehended Maggie in calling her irrational; a recognition that that diagnosis was inadequate, that he did not know how to read her actions, would be the first step towards the 
recognition of her reasons. See Loesberg, "Aesthetics, Ethics, and Unreadable Acts in George Eliot," in Knowing the Past: Victorian Literature and Culture, ed. Anger (Ithaca: Cornell Univ. Press, 2001), 134.

${ }^{44}$ Anger, Victorian Interpretation, 99.

${ }^{45}$ Greiner, "Sympathy Time: Adam Smith, George Eliot, and The Realist Novel," Narrative 17.3 (2009): 296.

${ }^{46}$ Greiner, "Sympathy Time," 297.

${ }^{47}$ Eliot, Adam Bede (New York: Penguin, 1980), 488. Hereafter abbreviated AB and cited parenthetically by page number.

${ }^{48}$ This distinction between sympathy and pity is in keeping with James Arnett's recent work on Eliot and Baruch de Spinoza; quoting Spinoza, he writes that pity is "bad and useless," and Deronda's sympathy is a much more cultivated and rational faculty ("Daniel Deronda, Professor of Spinoza," Victorian Literature and Culture 44.4 [2016]: 842).

${ }^{49}$ Eliot, The Lifted Veil (University Park: Pennsylvania State Electronic Classics, 2001), 13 .

${ }^{50}$ Eliot, The Lifted Veil, 14.

${ }^{51}$ Lallier, 78 .

${ }^{52}$ In portraying Eliot this way, my account is in significant disagreement with the very subtle account of Eliot that Cara Weber has recently developed. For Weber, it is a mistake to see sympathy as founded on identification: Eliot sees the self as a dynamic process, not as a stable entity, and thus sympathy with another involves an affective and intellectual exchange over time, not a single act of transformative fellow feeling. As is perhaps clear, in my view this overlooks Eliot's emphasis on the stability moral principle can provide. See C. Weber, “The Continuity of Married Companionship': Marriage, Sympathy, and the Self in Middlemarch," Nineteenth-Century Literature 66.4 (2012): 494-530.

${ }^{53}$ Famously, of course, Eliot translated Ludwig Feuerbach's The Essence of Christianity in 1852, and read deeply in the German Higher Criticism of the Bible. See, in this regard, Rosemary Ashton's chapter on Eliot in The German Idea (London: Cambridge Univ. Press, 1980); and her chapter "Life with Lewes: Weimar and Berlin," in George Eliot: A Life (New York: Penguin, 1997), 108-34. Moreover, Eliot remarks, in an oft-quoted passage, that "with the ideas of Feuerbach I everywhere agree" (The George Eliot Letters, Volume II, ed. Gordon S. Haight [New Haven: Yale Univ. Press, 1954], 153).

${ }^{54}$ Kant, 4:429, 4:428. Eliot had a positive reaction to this component of Kant's thought, referring in her revision of G. H. Lewes's Problems of Life and Mind (1879) to "Kant's fine phrase, 'Man refuses to violate in his own person the dignity of humanity" (Collins, 490). See Collins for a discussion of Eliot's role in preparing the text and for a comparison of Lewes's manuscript and the version Eliot published.

${ }^{55}$ Kant, 4:430, emphasis original.

${ }^{56}$ Coleman notes the revealing similarity between Kant's example and Fred Vincy's loan from Caleb Garth (see George Eliot and Money, 95).

${ }^{57}$ David Velleman, "Love as a Moral Emotion," Ethics 109.2 (1999): 360. Hereafter abbreviated $L M E$ and cited parenthetically by page number.

${ }^{58}$ Feuerbach, The Essence of Christianity, trans. Marian Evans (New York: Prometheus, 1989), 268-69.

${ }^{59}$ Feuerbach, 269. I dwell on Feuerbach's conception of love because it's one of the main roots of Eliot's conception of sympathy, to the extent that when she uses Feuerbach's arguments, the two words become interchangeable. For instance, in her 
critique of Dr. Cumming, she writes that his God, "instead of sharing and aiding our human sympathies," interferes with them by forbidding people "to feel for each other except in relation to Him" (Essays, 188, emphasis mine). This is a direct borrowing of Feuerbach's argument that the traditional notion of Christ destroys "the very soul of love," since it alters human relationships in such a way that "my fellow man is an object of love to me only on account of his resemblance of relation to this model" (268, emphasis mine).

${ }^{60}$ See Jaffe, Scenes of Sympathy, 133. In a recent paper that touches on this issue, Cristina Griffin has characterized Daniel Deronda as distinguishing between "impartial sympathy" and "sympathy practical," where the latter involves the specification and embodiment the former precludes ("George Eliot's Feuerbach: Senses, Sympathy, Omniscience, and Secularism," ELH 84.2 [2017]: 483).

${ }^{61}$ It is ironic that Casaubon famously has "two white moles with hairs on them," for Dorothea's pity is something akin to Velleman's wart-loving fetishist $(M, 42)$.

${ }^{62}$ See Korsgaard, The Constitution of Agency, 207-8.

${ }^{63}$ To mention two instances, T. H. Irwin distinguishes between cognitive sympathy, affective sympathy, and practical sympathy (see "Sympathy and the Basis of Morality," in A Companion to George Eliot, 279-93). Meanwhile, Leona Toker sees ideological sympathy, resonating sympathy, and redistributive sympathy (see Towards the Ethics of Form in Fiction: Narratives of Cultural Remission [Columbus: Ohio State Univ. Press, 2010], 121-22).

${ }^{64}$ Eliot, Romola, 95.

${ }^{65}$ See D. A. Miller, 184.

${ }^{66}$ As Hina Nazar notes, Dorothea here reminds Lydgate of the "full potential of the species" ("Philosophy in the Bedroom," The Yale Journal of Criticism 15.2 [2002]: 309).

${ }^{67} \mathrm{I}$ offer my own attempt at answering them in my essay, "The Scourge of the Unwilling': George Eliot on the Sources of Normativity," forthcoming.

${ }^{68}$ See Patrick Fessenbecker, "In Defense of Paraphrase," New Literary History 44.1 (2013): 117-39.

${ }^{69}$ Although somewhat dated now, perhaps the best history of Victorian moral philosophy is still Jerome Schneewind, Sidgwick's Ethics and Victorian Moral Philosophy (Oxford: Oxford Univ. Press, 1977). But see also Stefan Collini, Public Moralists (Oxford: Clarendon, 1991), which has little interest in Eliot as a serious thinker. For a more recent and quite clear account of the intuitionist-utilitarian debate and its subsequent influence on narrative theory, see Jesse Rosenthal, Good Form (Princeton: Princeton Univ. Press, 2017), esp. 17-21. 